\title{
STRAWBERRY JAM AND ROASTED CHICKEN: GENDER, CORPOREALITY, AND IDENTITY FORMATION IN MARILÓ SECO'S MERMELADA DE FRESA (1999)
}

\author{
MERMELADA DE FRESA Y POLLO AL HORNO: GÉNERO, \\ CUERPO E IDENTIDAD EN MERMELADA DE FRESA, DE \\ MARILÓ SECO (1999)
}

\author{
Nina NAMASTE \\ Elon University, North Carolina \\ nnamaste@elon.edu \\ orcid.org/0000-0003-3694-2019
}

\begin{abstract}
Mariló Seco's one-act play, Mermelada de fresa (1999), employs particular items of food to portray the difficulties that can arise in the process of navigating both society's and an individual's expectations. Generational differences about the role of women, plus the mix of traditional and contemporary values in 1990s Spanish society create an overabundance of behavioral expectations for Ella. Her coping mechanisms, displayed by the strawberry jam ritual, turn out to be dysfunctional because she focuses only on the physical representation of the female role (beauty, sexual activity) to the detriment of the psychological self. The contested roasted chicken echoes men's consumption of women because it represents another commodity or object of gratification for the men. Culinary imagery and metaphors in Mermelada de fresa expose the mounting demands and complexity in satisfying an escalating number of often contradictory roles that exist for any individual, but particularly for women, in a pluralistic society.
\end{abstract}

Keywords: gender identity, culinary imagery, social expectations, corporeality, role conflict. 


\section{Resumen}

La obra de teatro de un acto Mermelada de fresa (1999), de Mariló Seco, específicamente usa comida para representar las dificultades que pueden resultar del proceso de navegar las expectativas sociales e individuales. Diferencias generacionales sobre el rol de las mujeres, más una combinación de valores tradicionales y contemporáneos en la sociedad española de los años 90 , crean una abundancia de expectativas para la protagonista, Ella. Sus maneras de lidiar con los problemas, ejemplificadas por su ritual de mermelada de fresa, resultan ser inefectivas porque solo se enfocan en el aspecto físico del rol de ser mujer (belleza, relaciones sexuales, etc.), lo cual perjudica su estado mental. El pollo al horno representa el consumo masculino, figurativo y literal, de mujeres, ya que es otro objeto de gratificación. La comida y las metáforas de consumo en Mermelada de fresa exponen las dificultades para cumplir las normas sociales, roles y expectativas, que son frecuentemente contradictorias para cualquier individuo, pero particularmente para las mujeres, en una sociedad plural.

Palabras clave: identidad, comida, expectativas sociales, cuerpo, conflicto. 
The «nutritional arts,» to use Michel de Certeau's term, form a nexus of the complex social and cultural issues related to food, eating, and cooking. These arts encompass the physical, physiological, and affective activities related to production (shopping, cooking, combining ingredients, presenting, and serving meals) and consumption (food taboos, social interactions, tastes, and the acts of digestion and excretion $)^{1}$. Whether a solitary or social act, eating in any society has codes or behaviors that promote social, cultural, and historical mores. Gender roles and definitions of masculinity and femininity are reinforced by cooking practices, household management, and delineated spaces. In addition, relationships of control and power dictate the time, place, quantity, and quality of foods people eat. Self-destructive diseases, such as bulimia and anorexia, manifest a struggle between the body, the mind, and perceived notions of an ideal. The sensorial and often the sensual nature of eating reveals its relationship to sexual appetite. Furthermore, issues of socio-economic class distinctions, affective attachments through memory and nostalgia, geographic and cultural markers, as well as struggles between public and private spheres all demonstrate the multi-faceted, polemical connections between food and society.

The plastic, performative, and literary arts present, for a distinct purpose, the politicized and transgressive nature of food. In literary works, allegorical uses of eating, devouring, and cannibalism often expose structures of power. For instance, tropes of consumption, either of items or of people, represent an extreme capitalistic, consumer driven economy so as to demonstrate social inequalities and imbalances. Symptoms of excess associated with hunger and gluttony metaphorically stand for the extravagances of a society or a political regime. Through the deliberate inclusion of allegoric food-related references, authors frequently imbed a discourse of critique and transgression into their works. Consequently, the varied representation of the «nutritional arts» within literary texts becomes a mechanism to discuss the negotiation of culture.

1. The growing consumer market for cooking utensils, food-related television programming, diets, cookbooks, and products that promise professional results at home illustrates the fashions and fads to which even culinary topics are susceptible. 
Specifically in twentieth-century Peninsular drama, significant socio-historic, political, and cultural aspects of identity formation are explored through gastronomic imagery. The appearance or lack of food is not simply mentioned in passing, but is rather a means for the authors to process the country's socio-historical and political struggles. The presence of culinary images in works of literature is far from mere costumbristic detail but, rather, is a means of describing the individual and structural forces that contribute to identity struggles in particular moments of socio-historical development.

The death of General Francisco Franco in 1975, who had ruled Spain since 1939, ushered in a gradual transition to democratic rule, and with it came the usual difficulties of a pluralistic society. With the change from a dictatorship to a parliamentary monarchy, the struggle to construct identity shifted from individuals behaving in relation to the government's expectations to behaving in relation to other individuals' expectations. Under the dictatorship, Franco's regime «instructed» the citizens on what roles they were to fulfill and how to enact them appropriately. In contrast, Spain's democratic society grants freedoms, independence, and choices, which in turn increase the total number and sources of codes, rules, expectations, and behaviors. During both dictatorial and democratic times identity is based on roles of social expectations, but it is the type, number and sources of expectations that increase with the development of a pluralistic society. The additional options and possibilities often create a burden of choice because of the numerous and potentially conflicting social expectations.

Spanish society underwent vast political, economic, and social change after the signing of the 1978 constitution, which caused a «confused and confusing hybridity» (Graham and Sánchez 408). For example, the government granted regional control through the establishment of autonomous regions, which allowed for economic and cultural self-determination. Also, economic industrialization leapt forward to attain a level similar to that of the rest of Europe. Yet concurrent with Spain's rapid modernization, outdated forms of male dominance, sexual prejudice, and racism still existed (Graham and Sánchez 408-10; Brooksbank Jones 1995, 390). Therefore, Spanish culture in the 1980s and 1990s encompassed both anachronistic and contemporary characteristics, which may have caused confusion or disorientation at times. Helen Graham and Antonio Sánchez termed it «cultural schizophrenia» so as to define «the disorienting effects on Spaniards' consciousness of the speed and complexity of the changes that have radically altered their society over the last thirty years [1960s-1990s]» (408). Moreover, heterogeneity characterized Spanish society of the late twentieth century, and as Jo Labanyi states, «Spanishness is a shifting 
concept, encompassing plurality and contradiction» (396). Whereas in dictatorial times the regime closed national boundaries to outside influence and attempted to impose the definition of what it meant to be Spanish, in the last two decades of the twentieth century many groups co-existed and competed to define and delineate a Spanish identity, or rather identities.

Questions about fragmentation and exploration of identity form a core characteristic in Spanish drama at the end of the twentieth-century. In fact, «Spanish theatre in the 1990s is interested in the individual, but for an individual that has lost his/her coherence, unity, and autonomy» and «The characters in contemporary theatre encounter not only incoherence and fragmentation of the world in which she/he lives, but also the fragmentation and dissolution of her/his self» (Floek 2003, 48) ${ }^{2}$. Loneliness and the crisis of identity that leads to violence is another central characteristic, yet that violence isn't social or political in nature, but rather entirely personal and interpersonal explosions of violence (Floek 2004, 201). Susanne Hartwig, in her article about fragmentation in contemporary drama states, «Many of the hybrid texts utilize spatial-temporal ruptures and modes that do not affect the coherence of the principal storyline» (228). She goes on to say that the use of fragmentation, though not new, is different in that it doesn't aim to propel audience members to be agents of social change (such as in Brechtian theatre) nor does it connote a nostalgic desire for unity and plentitude (235). Mariló Seco's Mermelada de fresa exemplifies characteristics of drama written during this time period in that the protagonist is in the active process of fragmentation and dissolution, her identity crisis leads to personal violence, and the text itself breaks with linear and chronological time and space.

Though most known for her voice on radio shows (currently Canal Sur Radio Andalucía) and film dubbings, Mariló Seco is nonetheless part of a cohort of young Spanish dramatists writing in the mid -and late- 1990s. Born in 1962, Mariló Seco trained in voice and piano at a conservatory and then went on to get a degree in Dramatic Arts (Ortega 17). Her play PARA. NO. YA (1996) garnered acclaim from the Comisión de Lectura del Centro Andaluz de Teatro in that same year (Ortega 124). The anthology of female Andalucian playwrites, to which Mermelada de fresa pertains, describes the three authors as having their works staged, but not printed, and that the three female dramatists aren't very well known, thus, and precisely thus, their inclusion in the anthology (Ortega 7). María José Ragué-Arias documents well the upsurge of

2. All translations of the referenced scholarly articles, plus the dramatic text itself, are my own. 
women dramatists in the 1990s and their more noticeable and strong presence in the literary world. Seco's drama shares the central tenets of Spanish theatre of the 1990s in that the play Mermelada de fresa presents the struggle for individuality and self-identity in a democratic society and the food items function as a literary device to discuss the creation, negotiation and destruction of individual identities.

Identity, according to leading identity theorists Sheldon Stryker and Peter Burke, is the identification with a perceived role, the subsequent actions a person takes due to these constructed meanings, and the person's resulting concept of self (284). Roles, in sociological terms, are the behaviors and characteristics that fulfill perceived expectations. Social expectations delineate the roles in which people participate, multiple roles come together to create identities, and multiple identities create a total sense of self (Stryker and Burke 284). Relationships between people create expectations of behavior, which then leads to the formation of a self-definition. Socio-historical contexts and agents of socialization, such as family and school, help create the social expectations that become the structure of identity. Noting the constraint imposed on individuals through social roles and expectations of behavior, Karen Cerulo adds that «subjective definitions imprison individuals in spheres of prescribed action and expectation» (388). Though every choice has a social consequence of not fulfilling an expectation, individuals, significantly, choose whether to participate or not in those roles. Most often, social expectations and individual choice are not in opposition, but ultimately role clashes are difficult to escape because whenever a choice is to be made there is the potential for conflict. Individuals must prioritize the multiple expectations they perceive are placed on them, and choose the roles, or behavior, to exhibit. Most often, those unconscious choices are influenced by «master status» identities, or the most salient identities, which impact how the self is constructed. The self can be conceived of as a hierarchical interconnection of identities, with some identities prioritized and more prevalent than others based on the situation and context. Ella, the drama's protagonist, exemplifies the discord that can exist between roles and their, sometimes, conflicting expectations, especially when those expectations are connected to a master status such as gender.

The one-act play Mermelada de fresa, written in 1999 by Spanish dramatist Mariló Seco, exposes the mounting demands and complexity in satisfying an escalating number of, often contradictory, role expectations that exist for women in a pluralistic society and, thus, difficulties in creating a sense of self. Mermelada de fresa employs particular items of food, such as strawberry jam 
and a roasted chicken, to explore the ways in which freedom and increased choices can breed contradiction, confusion, and conflict.

\section{MERMELADA DE FRESA}

This eighteen-scene, one-act play opens with Ella attempting to relax by ritualistically working strawberry preserves into her hair in reaction to remembering an argument at the end of a date. He expects sex, something she does not see as a logical consequence of their date. In the ensuing scenes Ella theorizes that men and women cannot be friends because sex always interferes. Her encounters with men are persistently negative: she verbally spars with former boyfriends, and in a meeting the men organize to «talk» to her, they almost successfully gang rape her. Tension also exists among female relationships: Madre gives her food and questions Ella's ability to care for herself, while her roommate, Amiga, vacillates between consoling her and pointing out that Ella is to blame for her own unhappiness. As a solution to her problems, Ella meets numerous times with a hired hit-man, Asesino, asking him to kill people on a list she gives him. She appears uncertain as to whether the men or the women in her life are the source of her problems, and as a result changes the names on the death list frequently. Ella meets with Asesino one last time and tells him to kill the last person on the list. The play concludes with Ella sitting at the kitchen table spreading strawberry preserves on her hair while Asesino enters through the kitchen door and points a gun at her head.

Désiré Ortega Cerpa states, in the prologue to the drama, that Seco's works routinely have characters who straddle the edge of sanity, resisting, but also ready, to fall off the edge into the abyss of mental illness (18). Since the eighteen scenes frequently leap across linear time and space and present a fragmented, discontinuous reality it is impossible to know if what is happening is real or imagined by a mentally ill person (Ortega Cerpa 19). Thus, Mermelada de fresa infers mental instability through textual fragmentation as well as the main protagonist because of her inability to accommodate social and individual pressures. Yet, the question isn't «is Ella crazy», but rather «why is Ella pushed to the edge of sanity and why doesn't she have a viable, satisfying way to construct her personal identity, particularly a feminine one?» The textual and personal fragmentation fits into dramaturgical trends of the 1990s as noted above; indeed, the fragmentation offers a means to analyze and criticize a society that makes women feel disoriented by the multitude of social expectations, particularly those related to gender. While Ella vacillates on whom to blame as the source of her problems, men or women, the text posits that the 
core problem is the "crazy» society that expects individuals to happily enact restrictive, stereotypical gender roles.

Mariló Seco's Mermelada de fresa demonstrates the nature of constraint on identity. Ella's core problem centers on the demands and complexity of satisfying an increasing number of roles, and the changing expectations that go along with those roles, that exist for any individual in a contemporary, pluralistic society. She does not know which expectations to fulfill in her role as daughter, friend, girlfriend, and «modern» woman because often the expectations from one role contradict the expectations from another role. There are so many conflicting expectations of behavior that Ella is rendered almost «role-less». In fact, the characters' names indicate such in that Amiga (Friend) and Madre (Mother) have names associated with their roles, but Ella (She) is identified by her gender alone. Contrastingly, all the male characters have proper names (Carlos, Roberto, etc.), implying that men aren't defined by their roles, but by their individual personhood. While Ella identifies with being a woman, her «master status» or most prominent identity, the concept and definition of being a woman is in flux for her and for women, socially and historically, in 1990s Spain. Since the definition of woman includes so many disorienting traditional and modern expectations that are constantly being negotiated and defined socially, gender identity isn't something that Ella can use to stabilize her own sense of self. Ella can't delineate what it means for her to be a woman within contemporary Spain, therefore, Ella's sense of self is focused on an identity she can't define. Ultimately, an unstable, undefined, indefinite and unfulfilling sense of self leads to psychological turmoil, which for her leads to suicide. The balance between society's and the individual's expectations of behavior, combined with the increase in available roles a person can fulfill, can lead to an individual's struggle, and, sometimes, an inability to create a cohesive sense of self. Seco presents a decidedly negative potential reaction by an individual to overwhelming and conflicting perceived social expectations, all within a frame of culinary imagery.

The food items in Mermelada de fresa illustrate the protagonist's malfunctioning, unidimensional coping mechanisms, created in reaction to the overwhelming, multidimensional and conflicting social expectations placed on contemporary women. The only thing that provides solace to Ella is the ritual of spreading strawberry preserves on her hair, yet the act, though soothing, does not solve her problems. She states that of all the things she has done over the years to make herself look better, putting the red jam in her hair persists: «seriously, it falls out less and shines much more, on top of that it relaxes me and is very pleasant» (148). Amiga does not agree or share her enthusiasm for 
the product, but Ella appears not to care because it is the only thing that she does purely for her own enjoyment and pleasure, even if it is only temporarily satisfying. Ella applies marmalade to her hair three times: at the start of the drama when she is remembering a heated confrontation she had with her date about sex, after she has a disturbing conversation with Amiga's boyfriend about not making a difference in society, and at the end of the drama when she waits for Asesino to come kill her. In all three instances the ritual calms her agitated emotions, and in essence, serves as her momentary escape after or before an emotionally conflictive situation.

Curiously, what makes Ella feel better is a food item that is not ingested. She does not eat her «comfort food», but rather spreads it onto dead cells (hair), which makes it a purely exterior and superficial act rather than a nutritional one. As a symbol, strawberries, a fruit associated with Venus, the Roman goddess of love, have historically been considered an aphrodisiac due to their heart or V shape. As a visual representation on stage, the strawberry jam, because of its blood-like color, can function as a mechanism of foreshadowing death. In addition, sugary foods, such as jams and cookies, are often associated with child-like innocence and the ritual may indicate her desire to evoke such. In the end, the ritual, even if she were to eat the preserves, cannot remedy her underlying mental anxieties because the strawberry jam remains within the realm of the corporeal and does not address her psychological needs.

Ella acknowledges society's influence in shaping her expectations and the resulting single-minded concern of her physical appearance. Though she admits the ludicrous nature of diets and «helpful hints» that appear in magazines, she nevertheless succumbs:

ELLA: (Reading a magazine.) Listen to this, (She reads.) «...if you really want to slim down, this is the moment, we have great news, a revolutionary method.»

AMIGA: Didn't you read me this last week?

ELLA: No, but it is the same thing; don't eat, exercise, don't smoke, don't drink alcohol, sleep eight hours nightly, use good quality creams and, presto!, the miracle will happen without you even noticing it.

AMIGA: You'll be an irrecoverable anorexic, with a depression as big as a house, but with an enviable figure.

ELLA: I'm fed up with all of it. I will never go on a diet again.

AMIGA: Sure. Until someone tells you about a marvelous new method and you won't be able to resist. Like the one with peaches and hard-boiled eggs. Who the hell thinks of these things, or thinks they work?!

ELLA: I do. I will never eat canned peaches again. I probably won't ever eat canned fruit again. (147) 
Even though Amiga and Ella agree on the destructive nature of these images and ideas, Ella nevertheless admits to having participated in such miracle makeovers and «revolutionary» methods. Ella didn't achieve the euphoria promised, but rather ended up abhorring canned peaches. The magazines, presenting false promises of happiness that center on women's physical looks rather than mental abilities and/or needs, construct and reflect the ways in which society defines women within the narrow realm of the corporeal. Susan Bordo in Unbearable Weight affirms that the body in Western culture has repeatedly been equated with the female while the mind is equated with the male (5). Futhermore, Bordo exposes the rhetoric in diets and food advertisements, which imply that «women's appetites require containment and control, whereas male hunger is legitimated and encouraged» (14). Ella, following society's messages about women's bodies, throughout the drama remains rooted in the physical, to the detriment of the mind and the heart.

The image of a roasted chicken acts as a sexual symbol and as a metaphor of men's consumption of women. Ella visits her mother before going to the party and, before leaving, Madre gives her a roasted chicken. Ella promises her mother she will put it in Roberto's refrigerator so the chicken does not spoil while Ella is at the party. The stuffed chicken becomes a point of contention after Ella escapes the attempted rape:

ROBERTO: Hey! You're forgetting the chicken.

ANTONIO: Don't worry, we'll eat it, toasting to your health. (Everyone laughs.)

ELLA: I hope it rots in your stomach, sons of a bitch! (She slams the door and leaves.) (158)

The image associated with a roasted chicken is that of a cavern; in this case the chicken is stuffed, thus presenting a symbolic doubling of the need for filling in a space. Linguistically, the closeness between pollo (chicken) and polla (slang for penis) also indicates the author's choice in granting a sexual connotation to a chicken. In addition, the image of a cellophane wrapped chicken presents the idea of women (meat) «on display» to be consumed by men. In this scene, the men cannot have Ella so they will use the food as another means of fulfillment. One commodity, woman, is replaced by another, a cooked bird, to be eaten. Women and food appear here to be nothing more than mere objects for the gratification of men's desires.

Along with the image of the chicken Ella describes men in terms of ingestion and expulsion. Ella tells Carlos, «you make me want to vomit» (157), after describing how he used Ella to date her former and present roommates. Since Ella blames the men for her miserable life, she asks Asesino to kill them: 
«They fucked up my life. It is their fault I feel like this. They are the irrefutable proof that my life is shit. I've had relationships with seven-eyed beasts, ready to destroy me, ready to devour me slowly like hungry rats» (159, my emphasis). The images in these scenes are that men devour and expel women, just like any other food they ingest.

Through their words and actions men are connected with both sexual aggression and unassuageable appetite. She complains, «I definitely can't go out with a man, I know or not, without at the end of the night him wanting to sleep with me» and concludes that male friends cannot exist for women (13132). Roberto confirms this notion when, after a date, he suggests they go up to his apartment for sex. In an even worse scenario, Roberto organizes a party for Ella in which he invites only her ex-boyfriends. Carlos, Roberto, Antonio, and Pedro tell her, «we all blame you for something. You are so stuck-up, I don't know who the hell you think you are, but now you are going to explain it to us» (157). Roberto interjects, «You look beautiful. (He caresses her hair.) All of a sudden, after all your rude comments, I think I want to do something other than just talk» (157). Though Pedro does not want to participate, recommending they leave her alone since they are not barbarians, Carlos, Roberto and Antonio attempt to gang rape Ella. The portrayal of men in the drama is decidedly negative; women, like food, are for men's consumption, gratification, and satiation.

The same image of the roasted chicken is used in relation to both females and males. For the men it functions as a sexual referent and a commodity, while for Ella it potentially acts as a punishment, since she wishes the chicken will rot in their stomachs, serving as a means to inflict revenge on her torturers. Moreover, for Madre it symbolizes her daughter's ineptness at providing for herself:

MADRE: Come on, take it. Don't be stubborn.

ELLA: I said no, I don't need it.

MADRE: I know, but it will save you time.

ELLA: You're right, tonight I won't have time to cook and tomorrow I leave early.

MADRE: See? Go ahead and grab it. It is in the fridge. All you have to do is heat it up.

ELLA: $\quad$ Fine. (She goes to the kitchen and returns with a large stuffed chicken wrapped in cellophane.)

MADRE: It will be much better than the one you make, that's for sure. (138)

Madre goes on to insist that Ella put the chicken in the refrigerator wherever she goes and not just leave it in the car. Madre thinks that Ella is incompetent at basic things such as cooking for herself, yet she knows that younger women 
are always in a hurry and pressed for time in work-related activities rather than domestic duties. Via the chicken, Madre concurrently upholds the traditional female role of caring and nurturing for others through food, while also stressing the change in women's roles. For the younger generation, the role of professional worker has replaced the domestic one. However, the young women in this drama are no better off than their mothers, because although conditions have changed and options have expanded, the focus for and by women is still on the physical aspects of their being.

Ella's relationships with women are as conflicted as those with men because Madre and Amiga, just like Ella, concentrate on the corporeal features of the self and defined in relation to food. When Ella visits, Madre comments on her appearance: «Look at you, you are a mess, you look like a licorice stick so dark and sickly» to which Ella responds, «Wow...thanks! So many hours sunbathing and exercising so that your mother sees you as a licorice stick» (138). The connection with candy, which has no nutritional value, is a clear denigration. Both Madre and Amiga treat Ella's angst as nothing more than a temporary phase instead of assessing the serious nature of the situation or helping Ella deal with her troubled mental state. After Ella shares her fears about the extreme emotions she experiences, Amiga retorts that it must be a second adolescence and a bad phase that will pass in due time. Amiga, in a statement reiterated later by Carlos, will even suggest, "What you need is a boyfriend» $(142,154)$ as if males, and by extension sex, were a viable solution to her problems. Amiga has the distance to notice the contorted, negative ideas diets and magazines suggest, but she cannot see that her suggestions of finding a boyfriend and riding out the phase perpetuate the same notions of womanhood rooted in, defined as, and limited by her body. Thus, one criticism in Mermelada de fresa centers on men's inability to treat women as anything other than a commodity, in addition to women's complicity in upholding a system that narrowly focuses on the physical dimension of women's bodies and promotes them as objects for men to enjoy.

The drama's imbedded criticism of the commodification of women connects to Spain's decades-long race for acquiring consumer products. Fueled by a favorable international climate and global economy, increased investments, and a renewed determination to improve living conditions, Spain experienced fifteen years (1960-1975) of unprecedented growth (Grugel 65; Longhurst 20). Once a strong rural economy, Spain in the 1960s became the sixth largest manufacturer of cars, an indication of its level of industrialization. With such an expansion, the acquisition of consumer goods rose dramatically. In 1960 five percent of households had electronic appliances, while sixteen years 
later almost ninety percent owned a television and a refrigerator; by 1976 forty-nine percent of households owned a car (Longhurst 17). The insistence on acquiring goods and consumer culture continued during Spain's transition to democracy; in the drama not only goods are commodified and consumed. Those that don't or can't fit into the social expectations, such as Ella, are made to feel dispensable.

Ella cannot recognize the emotional sustenance, limited as it may be, her female relationships attempt to provide. After Ella explodes during a conversation and lays crying on the couch, Madre consoles Ella by making her an herbal tea, the quintessential «healing» drink, and by holding her hand. Yet despite their outright displays of concern, Ella tells Asesino to kill both Madre and Amiga precisely because of what she perceives to be the smothering effects the women have on her: «Yes, kill them both. That way they'll stop overwhelming me, stop telling me what I should do. Their affections and care suffocate me» (161). Instead of acknowledging Madre and Amiga's attempts at being supportive, even though they, too, are focused on the realm of the physical, Ella is tired of the soothing, nurturing care that the women offer, and, by extension, cannot comfortably inhabit the role of daughter or friend.

Social scientists Richard Ryan and Edward Deci find that identities are adopted to fulfill basic needs, such as connecting with others and experiencing belonging (254). If those identities aren't well internalized, because they don't fulfill basic needs, the less those identities foster mental well-being (Ryan and Deci 254-255). None of the relationships, roles nor expectations that Ella fulfills through those relationships provide connection and since «interpersonal relationships are among the most common constituent parts of the perception of the meaning and purpose of life» (Viewegh 5), Ella lives disconnected, unsatisfied, and confused; food items such as strawberry jam, chicken, licorice, «soothing» tea and metaphors of consumption (digestion and elimination) symbolically display such.

Seco voices, by means of the protagonist's relationship and role conflicts, constantly defined and delineated by food, the crisis many contemporary Spanish (and European) women endured. During the 1960s and after the death of Franco, women helped create the social reforms necessary to increase their presence in society and thus women's roles in Spanish society changed drastically. Women like Lidia Falcón, both feminist activist and playwright, participated in the Women's Liberation Movement to push for legal reforms of divorce, abortion, and contraception (Davies 183). By 1986 women made up over half of the work force, and by 1994 slightly over half of the university students were women (Davies 185), yet Anny Brooksbank Jones also documents 
the persistence of the «double shift» for most working women in the 1980s and 90s because domestic chores still fell primarily on them (1995, 390). According to these findings, contradictory expectations abounded within women's roles in Spanish society of the time. Brooksbank Jones further proposes that in the 1990s, Spanish women felt increased stress because of a value disorientation resulting from the fading traditional beliefs formerly promoted by the church and state $(1995,390)$. Graham and Sánchez posit that the combination of anachronistic and contemporary values creates disorientation due to postmodernity (408). They further note, «We are in a world [in the 1980s and 1990s] where social and national boundaries dissolve or coexist with emerging forms, accentuating the tendency towards cultural and social dislocation» (410).

Ella inhabits this world of the disoriented and dislocated. She describes herself as a confident, modern woman, declaring, "I've always known how to make decisions» (160), yet she changes her mind five times about whom Asesino should kill. Ella strives to epitomize the strong, liberated, determined, young Spanish woman, although she is riddled with self-doubt and continually questions what she wants, should be doing, and/or should have done. At a certain age the ability to go against social norms (work, marriage, home, children, happiness, etc.) becomes increasingly difficult thus often women in their thirties bend towards those social expectations to have career and family. The conflict between traditional and progressive expectations becomes more acute as well as the conflicts within those expectations. Significantly, Ella feels pressure from many sources to look good, to always be happy, to contribute to society in a meaningful way, and to aspire to the traditional female roles of wife and mother. These expectations confuse Ella because she does not know what to believe or seek, particularly because of the perception of herself as a thirty-year-old woman who should know what she desires.

To fulfill the role of sexually liberated and «modern» woman, Ella expresses the need to be sexual, but is detached from the people with whom she is intimate. For instance, she has a random sexual encounter with a stranger in an elevator on the way to meeting an ex-boyfriend. Ella accosts the man, who eventually acquiesces, has sex with him, and then leaves, all without speaking to him. When she arrives late, her excuse consists of «I was delayed in the elevator» (155). In addition, she tells Amiga about her frustration with the fact that in order to spend time with her ex-boyfriends, she has to agree to have sex with them or else they will not meet with her. Ella consents, but she never mentions any enjoyment or fulfillment from her encounters; her frustration signals she wants something more from her relationships but she is unable to reach any other level other than the purely physical. In many ways Ella 
is, to use Judith Butler's term, "performing gender» because she enacts the behaviors she perceives appropriate for a contemporary, urban, economically (and therefore sexually) independent woman. Gender is the social construct that defines appropriate behavior for the sexes and even though the "doer' is variably constructed in and through the deed» (Butler 181), Ella cannot gain satisfaction from fulfilling the role of woman because it only focuses on the physical self, to the detriment of her psychological one.

In addition to all the food-related interconnections with identity, other issues emerge related to forming a sense of identity within an increased world of choices and expanding expectations. The image of the thirty-something professional woman ends up being a false promise for Ella because she feels insecure about the choices she has made. Ella confesses to Amiga that she does not know what to do with her life and that maybe she should get married and have children (148), or in other words, perform the socially acceptable role of womanhood that includes matrimony and child rearing. Amiga asks what is wrong with Ella's life if she has a family that worries about her, various friends, and a job that she likes. Ella responds, "You're right, I shouldn't complain, so what is wrong with me?» (149), but she does not find an answer in herself or in Amiga's situation. Amiga provides the standard measure of success to which the two women aspire when she complains of her own perceived inadequacies:

[AMIGA:] I turned thirty long ago, I have my doubts and I hate to make decisions. I don't want to depend on anyone and my parents are elderly, plus I don't have any children and my job isn't the cure-all I thought it would be. I share an apartment with a neurotic woman, I've only slept with three different men in my life, it has been much too long since someone said «I love you» and my boyfriend is going bald... (149)

Amiga's response shows the disjuncture between expectations and reality: women, she suggests, should be decisive, independent, not need external affirmation, have a family, have a fulfilling job, have stable friends, be sexually adventurous and active, be loved, and, in general, not care about age nor mortality. The role of the professional superwoman is a false promise because it is neither attainable nor truly satisfying. Neither the role of aesthetically pleasurable object, created through beauty regimens or detached sexual encounters, nor the role as independent, decisive, working woman is viable because both roles focus only on the material rather than the mental and emotional aspects of life, plus the definitions of success and happiness are externally defined.

Of note is the way in which social expectations in this drama relate to stereotypes, particularly related to gender. The male characters, which, again, all have first names, are sex-obsessed, violent, and entitled, «devouring» and 
consuming women in their wake. The women, again, named only by their roles (Amiga, Madre), focus on physical appearance and traditionally «feminine» roles of woman, mother, homemaker and friend. Generically named Ella seeks to be the stereotypical modern woman who, literally, embodies it all: a sexually liberated, professional (worker) with an amazing physical appearance who finds meaning and purpose in life and connects with others. She is sexually free, but seemingly gains no pleasure from her heteronormative encounters. While an economically independent middle-class professional, work doesn't provide fulfillment. Her physical appearance is appealing to others, particularly men, but her being objectified and desirable likewise provides no joy or gratification. Her relationships and connections with others are fraught with difficulties, arguments, and strife. The ascribed identity of woman, rooted purely in the physical or corporeal realm, is not a role she can enact precisely because it doesn't meet her emotional and mental needs. In sum, all the gender-related stereotypes that she attempts to inhabit and enact do not work for her, and she has problems with those around her that inhabit equally stereotypical roles and behaviors.

Ella senses that she and the rest of her generation are useless, out of place, and disconnected. She voices her desire to make an impact, to have meaning in her life, and to be a part of history:

ELLA: Have you ever had the feeling that what we do is of no use whatsoever? For example, why are you here? Of what use are you? Throughout the ages there have been people who are useful to society and other useless, burdensome people. In this day and age, the second group far outnumbers the first and, of course, you and $\mathrm{I}$ are in that second group.

CARLOS: We aren't heroes or outstanding, but I'm sure we're doing something useful. Or, maybe, we're the irredeemable links in some human chain.

ELLA: That is it. That is exactly what we are, the stuffing in the chain. Maybe our entire generation is. We're misplaced, the «transition» generation. My parents, for example, talk about the past and they have something to tell: they survived the post-Civil war period. Or the hippie generation, they lived life differently, like they wanted to. (153)

Carlos thinks that Ella is going to drive herself crazy, analyzing everything so much. He suggests she should simply live life and have fun, like he does. Ella accusingly responds, «It is because of people like you that we don't evolve. You will guarantee that our generation passes unnoticed in the History of humanity» (153). According to Ella, the younger cohort lacks the collectivity, fabricated as it may be, that the previous generation experienced. The 
adolescents growing up during the transition period (1975-late 1980s), who later become the thirty-something group members in the 1990s, share the demanding need to adapt and expand social roles. The traditional male and female roles such as husband, father, wife, mother, all vestiges of the Franco regime that «instructed» the citizens on what roles they were to fulfill and how to enact them appropriately, needed to be combined with the progressive roles created during the last years of the dictatorship, transition to democracy and afterwards (educated, independent, female professional, for example). For Ella, the possibility of mediating traditional and contemporary expectations, both founded upon stereotypes, is unattainable.

Ella has moments of lucidity when she observes her own mental instability. In scene after scene, Ella moves from one extreme to the other, which even she alludes to as a sort of schizophrenia, leading her to the conclusion that death is her only viable option. Ella is worried because she has unexplained and drastic changes in emotions: «I haven't known how I truly feel for a long time now. I'm miserable, about to vomit, and the next moment I have a huge, unavoidable smile covering my face like an utter fool» (140). Her self-described Dr. Jeckyll and Mr. Hyde condition leads her to be happy one moment and suddenly have the desire to do harm, to kill someone, to make sure that some people disappear forever (141). After confessing her concerns to Amiga, Ella observes, «I've never really understood what the experts say about the many masks and the many people, within one person, that we are. For awhile now, I believe in schizophrenia, in multiple personalities» (140). The various masks and personalities that she mentions directly refer to the multiple roles, dependent on situations and relationships, which comprise identity. Ella aptly portrays the pendulum-like emotions many women feel when confronted with the multitude of changing, social expectations imposed on the modern, professional, urban, thirty-something woman. Ella, incapable of "playing» the disparate expectations and roles she perceives, finds her solution in contracted, assisted suicide.

Social scientists Richard Holmes and Stephen Holmes in their comprehensive book, Suicide. Theory, Practice and Investigation, discuss the interrelatedness of impulsive and violent behavior towards others and oneself (33). They present various theories regarding suicide, including the three connected dimensions of revenge/hate (a wish to kill), depression/hopelessness (a wish to die), and guilt (a wish to be killed) (34). They also describe common characteristics of suicides, which include unbearable psychological pain, a sense of aloneness and isolation, a growing self-realization that death is the only solution, inflexible thinking and an inability to see or complete solutions to problems, and, 
unmitigated hopelessness (Holmes and Holmes 34-35). In Mermelada de fresa, Ella embodies every one of these characteristics of suicides documented by social scientists. At first, she wanted to destroy the people with whom she had a relationship and, consequently, destroy the expectations she perceives others impose on her in that if she eradicates the relationships, she will abolish the attached social role expectations as well. In other words, if Madre no longer exists, Ella does not have to perform the role of daughter. In the end, she wants to destroy herself through contracted suicide because, if there is no self, there is no «battleground» on which to have to negotiate and live one's own and others' expectations. The uncertainty about how to perform all her roles leads Ella to choose suicide, which will ultimately erase her identity entirely.

Though she questions issues in her life, Ella's attempt at navigating society's mixed messages about young women's roles in society remains within the narrow realm of the physical: she applies strawberry preserves to her hair, subjects her body to extreme tanning and exercise regimens to be attractive to men, and has detached, sexual encounters. Enrique Gil Calvo argues that women use «womanly weapons» (sexual attractiveness, appearance, expression of identity) to control micro-level relationships and gain a sense of power, yet such weapons are useless at the macro-level because those very weapons objectify them via the male gaze. Those private or internal identities constructed on personal relationships with others may carve out some sense of power, but on the larger, social scale women are still dominated by male desires and modes (Gil Calvo 304). Since Ella remained objectified by those very elements that she did to provide her with a positive sense of self (strawberry jam ritual, diet, exercise), Ella cannot find power within the role of woman. Suicide is Ella's last act of control or individual choice and, therefore, an attempted rejection of social expectations, but the solution proves to be an equivalent unidimensional solution -the death of her physical body and the complete elimination of self.

Roles, in sociological terms, are the behaviors and characteristics that fulfill perceived expectations (Stryker and Burke 284). Multiple roles come together to create an individual's identity. Social expectations delineate the roles in which people participate, though there is also individual choice as to whether to participate or not in those roles. Most often, social expectations and individual choice are not in opposition, but ultimately role clashes are difficult to escape because whenever a choice is to be made there is the potential for conflict. Individuals must prioritize the multiple expectations they perceive are placed on them, and choose the roles, or behavior, to exhibit. Shelley Budgeon, in Choosing a Self, discusses the importance of choice in the delineation of an identity: 
Recent arguments have centered upon the assertion that within postmodernity the individual is increasingly freed from the constraints of ascribed identities that once were tightly organized through relations of class, race, sexuality, ethnicity, and gender, and must, therefore, construct his or her own internally referential identity within conditions of expanded choice. Questions surrounding how to live one's life have not only become central to identity, but the process of having to confront increased uncertainty and choice is itself productive of self-identity. (2)

The sense that Ella can enact her right to choose, for instance whom she wants killed, provides her with a sense of power, no matter how limited it may be. The inherent problem is that choice is structured by socio-historic conditions and under a continual state of revision or negotiation (Budgeon 6-7). The drama clearly depicts the lack of neatly discrete identities and the conflicts that can arise when a person feels forced to fulfill mutually competing roles; so too it depicts limiting socio-historic choice that Ella ultimately rejects.

Mariló Seco's Mermelada de fresa employs particular items of food, such as strawberry jam and a roasted chicken, to portray the difficulties that can arise in the process of filtering and prioritizing both society's and an individual's expectations of behavior. The drama exposes the mounting demands and complexity in satisfying an escalating number of seemingly contradictory roles that exist for any individual in a pluralistic society. Mermelada... renders the difficulty of navigating roles and creating an identity when there are so many options available because freedom and increased choices can potentially breed contradiction, confusion, and frustration. Generational differences about the role of women, plus the mix of traditional and contemporary values in Spanish society create an overabundance of behavioral expectations for Ella. The protagonist mixes social expectations with individual choice in an attempt at self-actualization, but the fusion causes a clash resulting in an identity crisis. Ella's coping mechanisms, displayed by the strawberry jam ritual, are dysfunctional because she focuses only on the physical representation of the female role (beauty, sexual activity) to the detriment of the psychological self. The contested roasted chicken echoes men's consumption of women because in the drama it represents another commodity or object of gratification for men. In the end, Ella vacillates between wanting to be an aesthetically pleasurable object and a self-fulfilled, professional woman, both of which turn out to be non-viable, unsatisfying options for her. Seco's protagonist cannot find any other alternatives because she feels the need to inhabit the extreme aspects of stereotypical, gendered behavior, expectations, and roles. The drama, thus, portrays the impossibility of satisfying multiple roles when individuals focus on only one aspect of their identity, particularly the corporeal. In addition, it 
depicts the confusion individuals experience as a result of socially defined roles and expectations that are always in a state of flux. As a result of the character's difficulty with and choices made in prioritizing roles, the dramatist shows the potential withdrawal, dislocation, and isolation of an individual from society, which in this drama leads to death.

After the decline of an oppressive ruler, members of society gain political freedom, but a much less visible and less obvious force governs their freedoms in a pluralistic society. The balance between society's and the individual's expectations of behavior, combined with the increase in available roles a person can fulfill, can lead to an individual's struggle, and, sometimes, an inability to create a cohesive sense of self, particularly when the roles are limited, limiting, and stereotypical. Mermelada de fresa exposes the mounting demands and complexity in satisfying an escalating number of often contradictory roles that exist for any individual in a pluralistic society.

\section{WORKS CITED}

Bordo, Susan. Unbearable Weight: Feminism, Western Culture, and the Body. Berkeley: University of California Press, 1993.

Brooksbank Jones, Anny. «Work, Women, and the Family: A Critical Perspective». Spanish Cultural Studies. Ed. Helen Graham and Jo Labanyi. NY: Oxford University Press, 1995. 386-395.

Brooksbank Jones, Anny. Women in Contemporary Spain. New York: St. Martin's, 1997.

Budgeon, Shelley. Choosing a Self: Young women and the Individualization of Identity. Westport, CT: Praeger, 2003.

Butler, Judith. Gender Trouble. NY: Routledge, 1999.

Certeau, Michel de, et al. The Practice of Everyday Life. Vol 2: Living and Cooking. Trans. Timothy Tomasik. Minneapolis: University of MN Press, 1998.

Cerulo, Karen. «Identity Construction: New Issues, New Directions». Annual Review of Sociology 23 (1997): 385-409.

Davies, Catherine. Spanish Women's Writing, 1849-1996. Atlantic Highlands, NJ: Athlone, 1998.

Floek, Wilfried. «Pérdida y búsqueda de identidad en el teatro de Yolanda Pallín». Identidad en el teatro español e hispanoamericano contemporáneo. Ed. Susanne Hartwig and Klaus Pörtl. Frankfurt: Valentia, 2003. 47-60.

Floek, Wilfried. «Entre posmodernidad y compromiso social. El teatro español a finales del siglo XX». Teatro y sociedad en la España actual. Ed. Wilfried Floeck and María Francisca Vilches de Frutos. Frankfurt: Iberoamericana, 2004. 189-207. 
Gil Calvo, Enrique. Medias miradas. Un análisis cultural de la imagen femenina. Barcelona: Anagrama, 2000.

Graham, Helen and Jo Labanyi, eds. Spanish Cultural Studies. NY: Oxford University Press, 1995.

Graham, Helen and Antonio Sánchez. «The Politics of 1992». Spanish Cultural Studies. Ed. Helen Graham and Jo Labanyi. NY: Oxford University Press, 1995. 406-418.

Grosz, Elizabeth. Volatile Bodies: Towards a Corporeal Feminism. Bloomington: Indiana UP, 1994.

Grugel, Jean and Tim Rees. Franco's Spain. London: Arnold, 1997.

Hartwig, Susanne. "¿Fragmentos, elipsis, huecos textuales? La escritura de los jóvenes autores dramáticos». Teatro y sociedad en la España actual. Ed. Wilfried Floeck and María Francisca Vilches de Frutos. Iberoamericana: Vervuert, 2004. 223-239.

Holmes, Ronald and Stephen Holmes. Suicide. Theory, Practice and Investigation. Thousand Oaks, CA: Sage, 2006.

Jordan, Barry and Rikki Morgan-Tamosunas, eds. Contemporary Spanish Cultural Studies. London: Arnold, 2000.

Labanyi, Jo. «Postmodernism and the Problem of Cultural Identity». Spanish Cultural Studies. Ed. Helen Graham and Jo Labanyi. NY: Oxford University Press, 1995. 396-406.

Labanyi, Jo, ed. Constructing Identity in Contemporary Spain. NY: Oxford University Press, 2002.

Longhurst, Alex. «Culture and Development: The Impact of 1960s 'desarrollismo'». Contemporary Spanish Cultural Studies. Ed. Barry Jordan and Rikki MorganTamosunas. London: Arnold, 2000. 17-28.

Nieva de la Paz, Pilar. «Luces y sombras de la nueva identidad femenina en el teatro español actual». Teatro y sociedad en la España actual. Ed. Wilfried Floeck and María Francisca Vilches de Frutos. Frankfurt: Iberoamericana, 2004. 65-86.

Ortega Cerpa, Désirée. Prologue (Prólogo) to La noche no duerme, Los gordos, Mermelada de fresa, by Mercedes León, Belén Boville Luca de Tena and Mariló Seco. Cádiz: Junta de Andalucía, 65-86, 5-19, 123-124.

Ragué-Arias, María José. ¿Nuevas dramaturgias? Los autores de fin de siglo en Cataluña, Valencia y Baleares. Madrid: INAEM, 2000.

Ragué-Arias, María José. El teatro de fin de milenio en España (De 1975 hasta hoy). Barcelona: Ariel, 1996.

Ryan, Richard and Edward Deci. «On Assimilating Identities to the Self: A SelfDetermination Theory Perspective on Internalization and Integrity within Cultures». Handbook of Self and Identity. Ed. Mark Leary and June Tangney. NY: Guilford Press, 2003. 253-272. 
Sánchez, Antonio. «Postmodernism and the Contemporary Spanish Avant-Garde». Contemporary Spanish Cultural Studies. Ed. Barry Jordan and Rikki MorganTamosunas. London: Arnold, 2000. 101-110.

Seco, Mariló. Mermelada de fresa. In La noche no duerme, Los gordos, Mermelada de fresa, by Mercedes León, Belén Boville Luca de Tena and Mariló Seco. Cádiz: Junta de Andalucía, 1999. 125-167.

Stryker, Sheldon, and Peter Burke. "The Past, Present, and Future of an Identity Theory». Social Psychology Quarterly 63.4 (2000): 284-297.

Valiente, Celia. «An Overview of Research on Gender in Spanish Society». Gender and Society 16.6 (2002): 767-792.

Viewegh, Josef. Suicide and Fiction: On the Concept of the Research into the Interplay Between Them. Brno: Psychologický ústav Akademie věd Ceské Republiky, 1998. 